\title{
Margaret McCartney: To the best of humankind, thank you
}

\author{
Margaret McCartney general practitioner
}

Glasgow

Barra is a tiny outer island of Scotland, a slight comma falling off the end of the landscape of the Outer Hebrides. Its runway is a white stretch of beach, embraced by the sea. The body of 14 year old Eilidh MacLeod was flown onto it, back to her home, after she was murdered in the recent terrorist attack in Manchester. With great dignity and to a pipers' lament, her friends and family received her body and took her to be buried. It is entirely, utterly, heartbreaking.

And then, Grenfell Tower. Dozens of people killed in a fire in "an accident waiting to happen," as residents predicted. ${ }^{1}$ I write this as a minority government now assembles a ragbag non-coalition, in chaos. It's hard to know how to respond to the hubris except to note that it's a repetition. I've been looking back through political biographies to try to understand. So many profoundly important decisions have so often rested on chance, coincidence, bargaining, and unexpected changes in a political environment.

Twenty five years ago I usually felt anxious driving through Northern Ireland on my way to Dublin, through the searchlights on the border. It was routine to be stopped by inquiring soldiers with guns. Now, I'm used to a border that's hardly obvious unless you know where to look. Brexit looms: what next?

The UK has, on average, been the second biggest arms dealer in the world over the past decade, ${ }^{1}$ selling arms to Saudi Arabia despite its multiple human rights violations. This should be incompatible with British values. Post-Brexit, who knows what trade deals we'll be made to swallow? I wonder where our underlying moral compass will point. It feels dangerously uncertain.

But some things feel less so. Public services and the NHS may be under profound pressure, but there is much to admire. The community groups surrounding Grenfell Tower offered the survivors immediate help, and the firefighters risked their own lives. The police and healthcare staff who have responded so admirably deserve our humble thanks. There is our strong and stable leadership, in spades. The professionalism, immediate sense of duty, and loyalty to the needs of people exemplify humankind's absolute best. I'm unlikely to come across the acute aftermath of terrorism, but the collegiate nature of the NHS means that we all feel concern for those who do that work.

The instability of the political stage compares badly with the selflessness and dedication of the NHS staff and emergency services

The instability of the political stage compares badly with the selflessness and dedication of the NHS staff and emergency services. Kirsty Boden, an Australian nurse, ran towards people in need of her help at London Bridge, towards her own death. This desperate tragedy makes the whole NHS family mourn. So often the systems we're organised into rub against each other: I doubt that we cherish each other enough.

I got out the poems of one of my loves from young adulthood, John Donne. You'll know the words, but they're worth drinking in again: "No man is an island entire of itself; every man is a piece of the continent, a part of the main; if a clod be washed away by the sea, Europe is the less, as well as if a promontory were, as well as any manner of thy friends or of thine own were; any man's death diminishes me, because I am involved in mankind. And therefore never send to know for whom the bell tolls; it tolls for thee."

May Eilidh, and everyone killed in these tragedies, rest in peace. May the staff who work beyond their written contracts to their own moral one know, at least, our appreciation.

\section{Competing interests: See www.bmj.com/about-bmj/freelance-} contributors/margaret-mccartney.

Provenance and peer review: Commissioned; not externally peer reviewed.

Follow Margaret on Twitter, @mgtmccartney

Grenfell Action Group. KCTMO-feeling the heat. 14 Mar 2017. https://grenfellactiongroup. wordpress.com $/ 2017 / 03 / 14 / \mathrm{kctmo}$-feeling-the-heat/.

Published by the BMJ Publishing Group Limited. For permission to use (where not already granted under a licence) please go to http://group.bmj.com/group/rights-licensing/ permissions 
